Japan. J. Physiol., 21, pp. 99-118, 1971

\title{
THE CHEMORECEPTION IN THE LATERAL-LINE ORGANS OF TELEOSTS
}

\author{
Yasuji Katsuki,* Toru HaShIMOTO** and \\ James I: KeNDALL \\ Laboratory of Sensory Sciences, University of Hawaii \\ Department of Zoology, University of Hawaii, Honolulu, Hawaii 96822, U.S.A.
}

\begin{abstract}
Summary 1) Chemoreception was investigated of the receptor end organ on the flank skin in several fresh water and sea water bony fish by recording the electrical responses in single fibers of the lateral-line nerve (X) and of the accessory lateral-line nerve (VII). Three species of fish, catfish (Ictalurus), mullet (Mugil) and carp (Cyprinus) were studied extensively.
\end{abstract}

2) Responses of the receptor organ to monovalent cations, $\mathrm{K}^{+}, \mathrm{Na}^{+}$, $\mathrm{Rb}^{+}, \mathrm{NH}_{4}^{+}, \mathrm{Li}^{+}$, and $\mathrm{Cs}^{+}$in the solution were observed on all fishes studied. Among them $\mathrm{K}^{+}$had the stronge'st effect. Inorganic anions were ineffective. In fresh water fish the sensitivity of the end organ was much superior to that of marine fish. The responses to various concentrations of $\mathrm{Na}^{+}$were almost parallel to responses to $\mathrm{K}^{+}$, although somewhat smaller in fresh water fish, while in marine fish the sensitivity to $\mathrm{Na}^{+}$was much inferior to that to $\mathrm{K}^{+}$. Such a fact may come from an abundance of $\mathrm{Na}^{+}$in the environment. In those end organs divalent cations like $\mathrm{Ca}^{++}, \mathrm{Mg}^{++}$and $\mathrm{Sr}^{++}$suppressed excitatory effects of monovalent cations when the former were applied simultaneously or in sequence to the end organ. Tetrodotoxin also produced a similar effect. Such suppressive effects were reversible. After rinsing the end organ with fresh water or sea water thoroughly, those effects subsided completely.

3) In euryhaline fish when they move from sea water to fresh water or vice versa, the sensitivity to $\mathrm{K}^{+}$and $\mathrm{Na}^{+}$changes within a certain period of time from the type of marine fish to that of fresh water fish or in the opposite direction. In a mullet the complete change of sensitivity of the end organ occurred in 7 days.

4) In the case of catfish there were observed a variety of responses to chemical stimuli, not only to monovalent cations but also to divalent

Received for publication January 22, 1971

勝木保次, 橋本 享

Present address: * Department of Physiology, Tokyo Medical and Dental University, Yushima, Bunkyo-ku, Tokyo 113, Japan. ** Institute for Medical and Dental Engineering, Tokyo Medical and Dental University, Surugadai, Kanda, Chiyoda-ku, Tokyo 101, Japan. 
ones and several others as well. Some fibers were very sensitive to $\mathrm{NH}_{4}{ }^{+}$, or specifically to quinine or glutamate. None of them responded to sugar.

5) Histological studies have disclosed that

(a) the catfish has various types of end organs innervated by the lateralline nerve and the accessory lateral-line nerve on the flank skin; canal neuromasts, large and small pit organs and many terminal buds.

(b) The mullet has 12 or 13 rows of the lateral-line organs on the flank skin. The scale along each lateral-line has a groove at its central part and a single neuromast is located in it. Through a small hole a few lateral-line nerve fibers reach to the end organ. Each groove is discrete and independent so that there is no lateral-line canal. From such structure of the lateral-line system the end organs in grooves are thought to be free neuromasts.

(c) On the flank skin of the carp there are free neuromasts and terminal buds as well as canal neuromasts. The terminal buds, however, are not as numerous as in the catfish.

Behaviorists have demonstrated that many species of teleosts are responsive to chemical stimuli not only in the mouth, pharynx and gill cavity but also over the entire surface of the body including the barbels and fins. PARKER (1912) found that the behavioral responses to chemical stimuli on the flank skin of Ameiurus no longer occurred after cutting the branch of the accessory lateral-line nerve (VII) that was considered to innervate the receptors there (HASLER, 1957). Based on these behavioral studies it is generally believed that the integument of most bony fishes may have specific receptors responsive to stimulation by mildly irritating chemical substances (BARDACH, 1967; HASLER, 1957; TEICHMAN, 1962). The chemical sense of the body surface has been referred to as the common chemical sense and attributed even to free nerve endings in the epidermis (BEIDLER, 1965; WHITEAR, 1952). Until now there has been no conclusive determination as to specific types of receptors, if any other than taste buds, responsive to chemical stimulation of the skin. On the other hand, very limited electrophysiological studies on the chemical sense have been carried out on fish. The gustatory sensation of the palatal organ of the carp was studied by KoNISHI $(1961 ; 1963 ; 1966 a, b$; $1967 \mathrm{a}, \mathrm{b} ; 1969)$ and that of the fin or barbel of a few species of marine and fresh water fishes was explored by BARDACH $(1966 ; 1967)$ and TATEDA (1964).

The palatal organ was considered to be a gustatory organ because of many taste buds observed there by Weber in 1827 (Herrick, 1903a). Similar receptors responsive to chemical stimulation on the body surface have been called terminal buds, although there have been conflicting interpretations regarding their function in the older literature (Weber, Leydig, Schultze, Merkel, Herrick and others) (Herrick, 1903a, b). The structural distinction between the terminal bud and 
the neuromast of the lateral-line system is based on the arrangement of the sensory and supporting cells. In the terminal bud, as in the taste bud, both the sensory and supporting cells extend from the basement membrane to the distal or free surface of the epithelial membrane while in the neuromast the sensory cells extend over only part of the way from the free surface through the epithelial membrane and fail to reach the basement membrane (HerRick, 1901; HerRICK, 1903a, b). Studies with the electron microscope have further disclosed structural differences between the sensory cells of the neuromast and the taste bud (FLOCK, 1966; HAMA, 1965; IWAI, 1967). In the neuromast, the hairlike process is composed of stereocilia and a single kinocilium; in the taste bud and terminal bud such differentiation is not present and all hairlike processes are composed of numerous microvilli (Hama, 1965; Szabo, 1965; UGA and Hama, 1967).

Contrary to the commonly accepted view of the chemical sense over the general body surface, Katsuki and others reported responses from shark pit organs to chemical stimulation. This was done by recording from single lateral-line nerve fibers innervating neuromasts of pit organs on the flank skin of sharks (KATSUKi et al., 1969; KATSUKi et al., 1970). HAMA and YAMADA (in preparation) confirmed electron-microscopically the ciliary structure of the hairlike process in these sensory cells. In a preliminary study (KATSUKI and HASHIMOTO, 1969) similar responses in the lateral-line system to chemical stimulation of the body surface in several species of teleosts have also been reported. The purpose of this paper is to present the results obtained on responses of the lateral-line system to chemical stimulation in more detail.

\section{MATERIALS AND METHODS}

Marine, fresh water, and euryhaline fish were used in the experiments. Two moray eels (Gymnothorax) represented the marine form; ten carp (Cyprinus) and ten catfish (Ictalurus) represented the fresh water form; eighteen mullets (Mugil) and nine cichlids (Tilapia) represented euryhaline fishes. All these fishes were obtainable in Hawaii. In addition, the Japanese eel (Anguilla), the conger eel (Astroconger), the carp and some other forms were examined in Tokyo.

The experimental approach was as uniform as possible in all the fish, considering the variety of fishes involved. First, the fish was anesthetized with MS $222(0.03-0.05 \mathrm{~g} /$ liter $)$ and then affixed to a board with the fish body out of water, but covered as much as possible with wet gauze kept moistened by salt or fresh water. The gills were irrigated with aerated water through a mouthpiece and the amount of water delivered was carefully controlled. When the volume of water was not properly controlled, the experiment was unsuccessful. Each fish required different amount of water depending on the species, the size and especially the habit of the fish. With proper control of water volume and oxygen supply the fish lay quietly on the board usually without further anesthesia, but additional 
MS 222 solution could be added as needed.

The lateral-line nerve was exposed near the operculum where it usually runs just beneath the skin so that a small incision readily exposed it. By using a pair of well sharpened tweezers, the distal cut end of the lateral-line nerve was separated under a binocular microscope into very small bundles of a few fibers. If necessary, such a small bundle was further divided until one or two fibers were obtained. The intactness of these fibers could be tested by recording their spontaneous electric discharges. The small nerve bundle or individual fibers were looped over a chlorinated silver wire electrode and a large $\mathrm{Ag}-\mathrm{AgCl}$ indifferent electrode was placed against the side of the fish's wet body. The nerve fiber discharges were then displayed on the oscilloscope (Tektronix Type 565) by a conventional cathode follower and a high gain RC-coupled amplifier.

Most records were registered on a strip chart recorder through an electronic rate meter as previously reported (KATSUKI et al., 1970). The impulse frequency of nerve discharges at a given time interval was registered on a paper by the rate meter, thus making possible observation of change in the impulse rate during experimentation. The advantage of this method is the precise computation without delay of the temporal and sequential change in the discharge rate of a single nerve fiber.

In many experiments, the accessory lateral-line nerve was also used. This nerve may be composed of as many as three branches: the dorsal, the medial, and the ventral (FrEIHOFER, 1963). The medial branch usually ran with the lateralline nerve and the separation of these two nerves from each other was almost impossible (SzABo, 1965; Tester and Kendall, 1967). The dorsal or ventral branch was more often used. Although the detailed anatomy of the accessory lateral-line nerve varied in different species, its exposure was accomplished without much trouble in each case as discussed later.

Most fibers showed spontaneous discharges and, whenever these were observed on the oscilloscope screen, the location of the end organ innervated by the nerve fiber was searched for by stimulation of the flank skin. When the end organ was a canal neuromast, its location was easily discovered by the train of discharges elicited by a vibratory stimulus or by a light touch with a soft brush around the receptor site. However, when the receptor was a pit organ (free neuromast) or a terminal bud, there was little or no sign of discharges in response to any vibratory stimuli on the flank skin. To discover an otherwise sensitive spot, a salt solution was applied over the skin of the body or an electric current pulse was applied to the skin through a small pair of bipolar electrodes with a tip distance of $1 \mathrm{~mm}$.

The end organ was considered to be a canal neuromast when a typical response pattern was elicited in response to light mechanical stimulation and almost no response following application of salt solution. When a certain potassium salt solution was applied to a site and a response was elicited to such chemical stimula- 
tion, then other diverse ionic solutions were presented and responses to them were registered on a paper. When marine fish were studied, the salt solutions were always kept isotonic with sea water by glucose $1.1 \mathrm{M}$ or sodium chloride $0.55 \mathrm{M}$ concentration.

Histological investigations were made for demonstration of structure and distribution of the receptors, and of their innervation. Materials for paraffin imbedding were fixed in formalin and Bouin's fluid. For tissue differentiation sections were stained with Heidenhain's iron hematoxylin and triosin; Gomori's aldehyde-fuchsin, hematoxylin and light green; Mallory's triple stain; and Bodian's protargol silver. Innervation of the receptors was studied after treatment of the integument with Gilbert's silver and Sihler's method (DAVENPORT, 1964).

\section{RESULTS}

Preliminary studies on the catfish, the carp, the mullet, the cichlid and the moray eel gave similar results in all species (KATSUKi and HASHimoto, 1970). Based on these results, the catfish (Ictalurus), mullet (Mugil), and carp (Cyprinus) were studied extensively since they were cultivated in Hawaii and readily available.

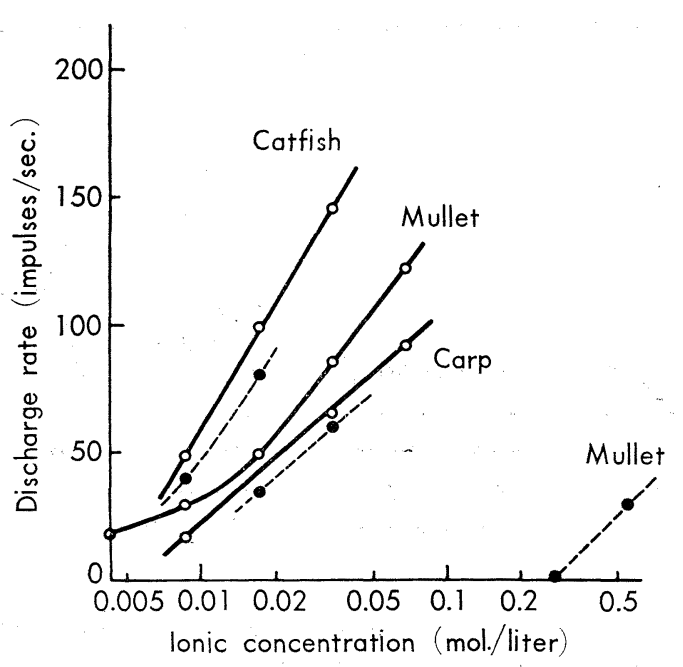

Fig. 1. Response characteristics to various concentrations of the applied salt solution. Ordinate: the impulse frequency of a single unit of the lateral-line nerve (impulses/ sec.). Abscissa: the molar concentration of the applied salt solution (mole/liter). The solid line indicates the response characteristics to $\mathrm{KCl}$ solution. The broken line shows the response of the same nerve fiber to $\mathrm{NaCl}$ solution. Materials: The catfish (Ictalurus) and the carp (Cyprinus) are fresh water fishes. The mullet (Mugil) is an euryhaline fish, which was raised in sea water. $-\mathrm{O}-\mathrm{KCl},-\mathrm{NaCl}$. 
Chemical stimuli were presented as various concentrations of potassium chloride and sodium chloride. Although each individual fish showed different responses, they showed the same tendencies, as indicated in Fig. 1. The rates of increase in the discharge rate elicited by potassium and sodium were almost parallel to each other, but the effect of the potassium was always stronger.

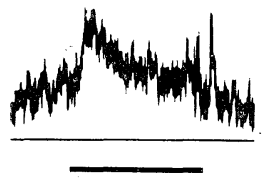

$\mathrm{NaCl} \quad 0.069 \mathrm{M}$

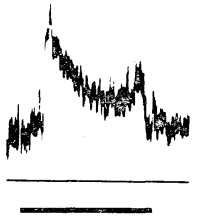

$\mathrm{KCl} 0.069 \mathrm{M}$
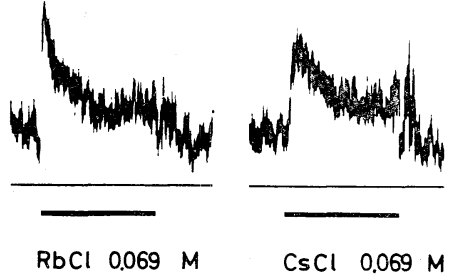

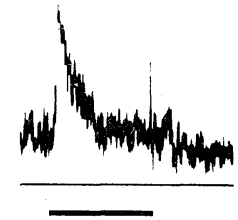

$\mathrm{NH}_{4} \mathrm{Cl} 0.034 \mathrm{M}$

$30 \mathrm{sec}$.
$50 \mathrm{impulses} / \mathrm{sec}$.

Fig. 2. Response pattern of a single lateral-line nerve fiber to monovalent cations. The traces show the records of the instantaneous discharge rate which were obtained by a rate meter. The applied solution caused the marked increase of the neural discharge rate. At the end of each salt application, the receptive field of the nerve fiber was rinsed with water and the applied cation was washed away. The applied salt and its concentration is shown below the respective response pattern. Material: the catfish (Ictalurus).

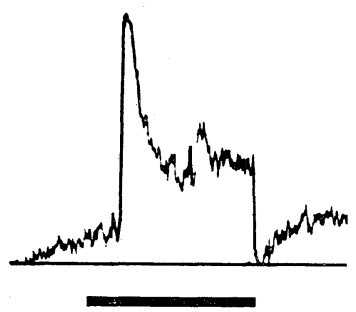

$\mathrm{KCl} 0.069 \mathrm{M}$

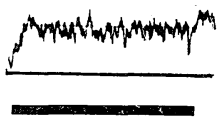

$\left(\begin{array}{ll}\mathrm{KCl} & 0.069 \mathrm{M} \\ \mathrm{CaCl} & 0.046 \mathrm{M}\end{array}\right.$

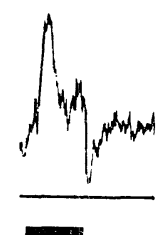

2 min. later $\mathrm{KCl} \quad 0.069 \mathrm{M}$

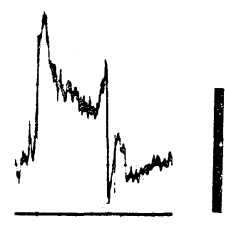

50 impulses/sec.

4 min. later

$\mathrm{KCl} 0.069 \mathrm{M}$

$30 \mathrm{sec}$.

Fig. 3. Suppressive effect of $\mathrm{Ca}^{++}$. $\mathrm{Ca}$ ions exert a suppressive effect on monovalent cationic responses, when they are applied with or before monovalent cationic solutions. From the left are shown the control response to $0.069 \mathrm{M} \mathrm{KCl}$ solution, the suppression by $\mathrm{Ca}$ ions in the applied mixed solution of $0.069 \mathrm{M} \mathrm{KCl}$ and $0.046 \mathrm{M} \mathrm{CaCl}$, and the subsequent recovery of the potassium response. After the cessation of the salt application the receptive field of the concerned afferent fiber was thoroughly rinsed with sea water many times, but the recovery from $\mathrm{Ca}$ suppression took a rather long time as shown by figures on the right. Material: The mullet (Mugil). The description of the time pattern of the response is the same as that of Fig. 2. 
In the case of the mullet, which came from the sea, the effect of the potassium ions was not very different from that observed in the fresh water fish, but that of sodium was much weaker. Concentrations of sodium ions smaller than those present in sea water produced almost no effect, while greater sodium concentrations caused little responses. Sodium chloride solutions of very high concentrations were not tested for fear of irreversible damage to the end organ. There is thus a great difference in the effect of potassium and sodium ions. The reason for this may be an adaptation of the receptor end organ to sodium ions in the surrounding medium so that the sensory cell membranes lose sensitivity to the sodium concentration below that in the medium. In contrast to the mullet, a fresh water fish like the catfish or carp usually lives in a poor ionic medium so

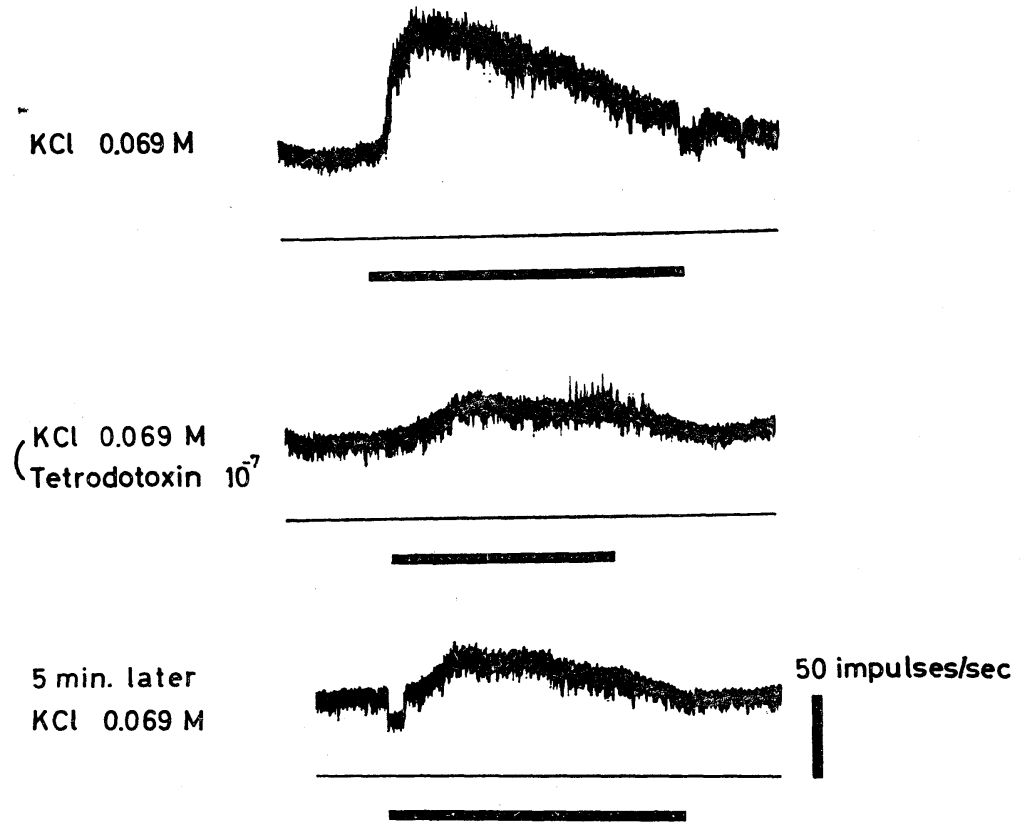

30 sec.

Fig. 4. Effect of tetrodotoxin. The very diluted tetrodotoxin $\left(10^{-7} \mathrm{~g} / \mathrm{ml}\right)$ had a suppressive effect on the receptor activity to the applied monovalent cation. Upper: The control response to $0.069 \mathrm{M} \mathrm{KCl}$. Middle: The suppression exerted by tetrodotoxin in the mixed solution of $0.069 \mathrm{M} \mathrm{KCl}$ and $10^{-7} \mathrm{~g} / \mathrm{ml}$ tetrodotoxin. Lower: The recovery of the receptor activity at 5 minutes after the cessation of the application of the mixed solution. Between the middle and the lower record the concerned receptor site was rinsed many times with sea water, but the recovery from the tetrodotoxin effect took about 10 minutes. Material: The mullet (Mugil). (See the legend of Fig. 2 on the response pattern description) 
that the sensory cell membranes may be very sensitive to both potassium and sodium ions.

Effects of other monovalent cations, namely, $\mathrm{Rb}^{+}, \mathrm{NH}_{4}^{+}, \mathrm{Cs}^{+}, \mathrm{Li}^{+}$were studied. As in sharks (KATSUKI et al., 1969; KATSUKI et al., 1970), all these ions were found to be effective on the receptor, although the effects were a little bit weaker than $\mathrm{K}^{+}$or $\mathrm{Na}^{+}$(Fig. 2). Simultaneous application of $\mathrm{Ca}^{++}$with potassium or sodium ions to the end organ suppressed the potassium or sodium effects in teleosts as in sharks (KATSUKI et al., 1969; KATSUKI et al., 1970). The recording on the extreme left in Fig. 3 shows a control response; the second one from the left in the same figure shows the suppression of the response to $\mathrm{K}^{+}$due to simultaneous delivery of $0.046 \mathrm{M} \mathrm{CaCl}_{2}$ solution. Two minutes after rinsing the end organ with sea water the same $\mathrm{K}^{+}$solution was presented again and the degree of recovery of response is shown in the third tracing of Fig. 3. Four minutes later, further recovery of response is shown in the fourth tracing of Fig. 3. This course of suppression and recovery is similar to that observed in sharks (KATSUKI et al., 1970). A $10^{-7} \mathrm{~g} / \mathrm{ml}$ solution of tetrodotoxin (Sankyo) strongly suppressed the response of the end organ (receptor) to $\mathrm{K}$ and $\mathrm{Na}$ ions, but after rinsing the suppressive effect subsided slowly (Fig. 4).

The mullet is an euryhaline fish and it was thought that, when the fish was sub-

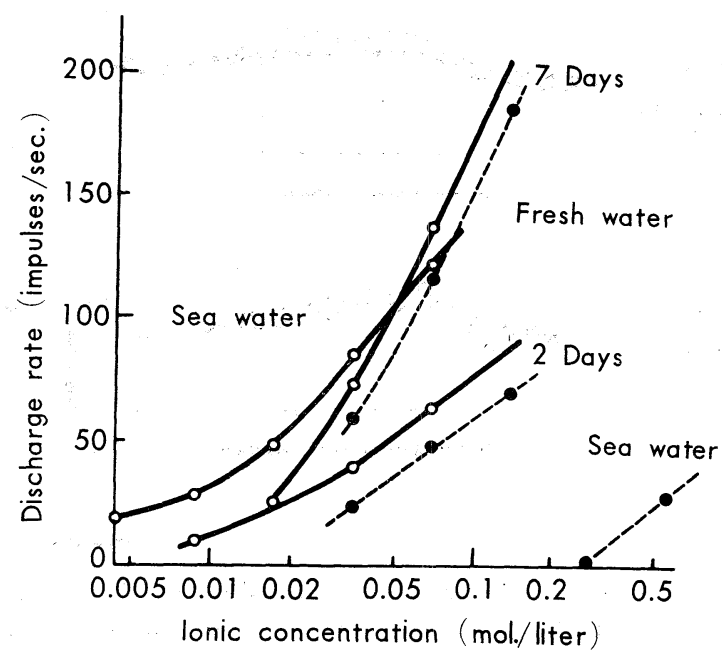

Fig. 5. Environmental ionic effect on the chemosensitivity of the lateral-line organ. The solid lines and the open circles are the responses to potassium chloride solutions. Ordinate: The discharge rate of the neural response (impulses/sec.). Abscissa: The molar, concentration of the applied salt solution. The mullets raised in sea water were moved into fresh water, and the change of the chemosensitivity was measured. (See text) 
jected to the greatly changed environmental condition by going from sea to fresh water, the receptor sensitivity to various ions might shift. As a first experiment, the sensitivity of the receptor of a mullet obtained from sea water to potassium and sodium ions was measured. The marked differences in sensitivity to those ions are shown in Fig. 5 by the curve on the extreme left (open circles) for potassium and the curve on the right for sodium (closed circles). At two to three hour intervals one fourth of fresh water was added until after twelve hours the sea water was completely replaced by fresh water. Two days later after the medium of sea water was changed to fresh water, the second experiment was performed. The movement of the fish became sluggish and the body surface was covered with thick mucus. An example of the results of the experiments on the effect of the change of medium is shown in the middle tracing of Fig. 5, where the sensitivity to potassium ions decreased slightly but that of sodium increased. Similar results were observed in several other experiments. After seven days in fresh water the fish regained its activity and experimental results on this fish are shown in the upper part of Fig. 5. Sensitivities to potassium and sodium were improved in a parallel manner, showing that the sensitivity to potassium was high in both salt and fresh water while that to sodium was low in salt water and high in fresh water. Such changes in the receptor sensitivity may probably be one of several physiological
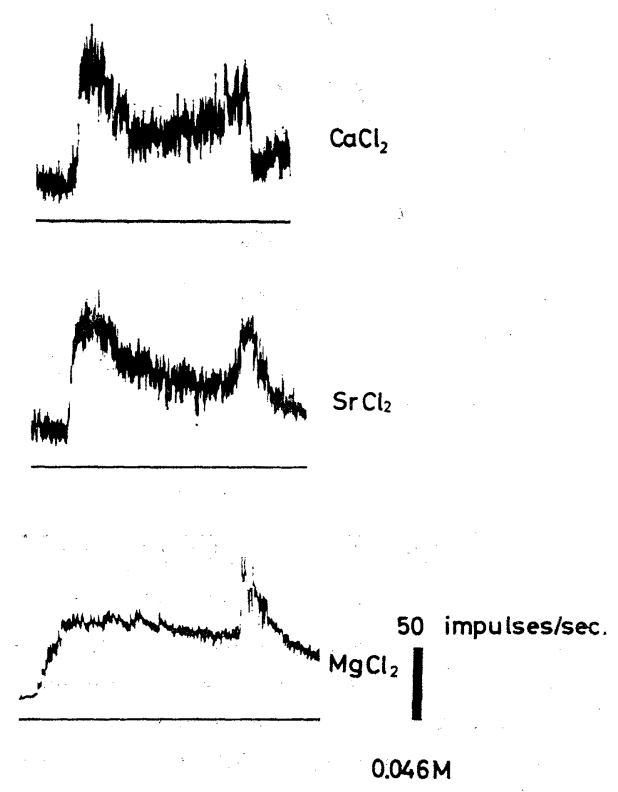

$30 \mathrm{sec}$.

Fig. 6. Excitatory effect of divalent cations on the lateral-line organ of a catfish. $0.046 \mathrm{M}$ divalent cationic solutions of $\mathrm{CaCl}_{2}, \mathrm{SrCl}_{2}$, and $\mathrm{MgCl}_{2}$ produced the excitatory responses. Compare with the suppressive effect shown in Fig. 3. 
adjustments that occur in the euryhaline fish upon the environmental change between salt and fresh water.

The catfish (Ictalurus punctatus) showed unexpectedly large differences in its responses to chemicals other than monovalent cationic solutions. Its skin receptors showed responses not only to various monovalent cations but also to other types of substances. For example, in other fishes calcium ions had a suppressive influence on the monovalent cation effect (Fig. 3). But an excitatory effect by calcium ions was observed in some fibers of the lateral-line nerve of the catfish. Other divalent cations like $\mathrm{Sr}^{++}$and $\mathrm{Mg}^{++}$also produced excitatory effects on the same end organ, but to a lesser degree than the calcium ions (Fig. 6). Monovalent cations like $\mathrm{K}^{+}, \mathrm{Na}^{+}$, and $\mathrm{NH}_{4}{ }^{+}$also produced excitatory effects on the above fibers, but the effects were weaker than those of the divalent cations (Fig. 7). The effect of tetrodotoxin on the receptor sensitivity was tested but no sign of suppression was observed by tetrodotoxin on the excitatory calcium effect. In previous experiments it was shown that tetrodotoxin depressed the membrane permeability to monovalent cations (KATSUKI et al., 1970).

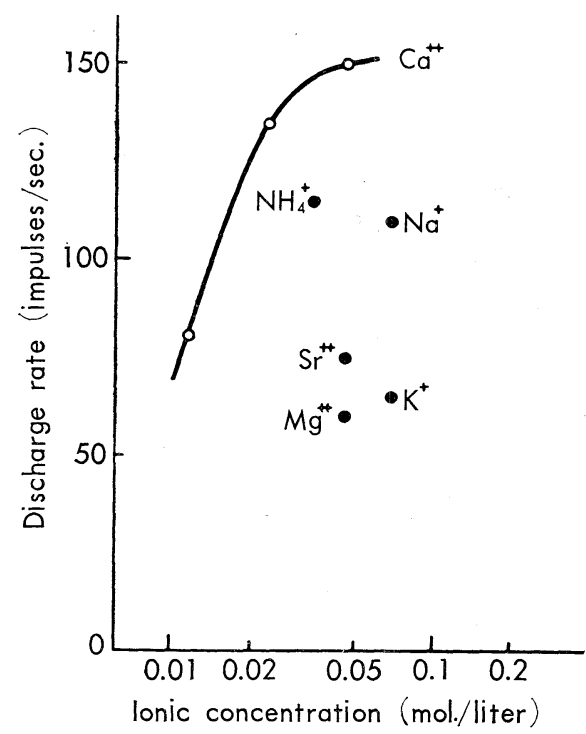

Fig. 7. Response characteristics of the lateral-line receptor sensitive to divalent cations as well as to monovalent cations. The solid curve and the open circles are the responses to $\mathrm{CaCl}_{2}$ of various concentrations. The labelled solid circles show the magnitude of the response to the various salt solutions. Material: The catfish (Ictalurus).

In addition, in the catfish there were nerve fibers that yielded a marked and specific response to $\mathrm{NH}_{4} \mathrm{Cl}$ solution (Fig. 8) but did not respond to $\mathrm{KCl}, \mathrm{NaCl}$, $\mathrm{RbCl}$ or tetraethylammonium chloride solutions. The end organ for these fibers may respond selectively to ammonium salts, recalling the work of TATEDA (1964) 
which reported high sensitivity of the barbel receptor to ammonium salts.

There was observed another kind of fibers, which produced a high response to sodium glutamate as well as that to various mono- or divalent cations, as shown in Fig. 9. This unusual response to sodium glutamate may be compared with that to sodium chloride in Fig. 10. The difference in the response magnitude is conspicuous despite the fact that the concentration of sodium glutamate is one third of that of sodium chloride. Therefore, glutamate ions are considered to be specifically effective to the end organ.

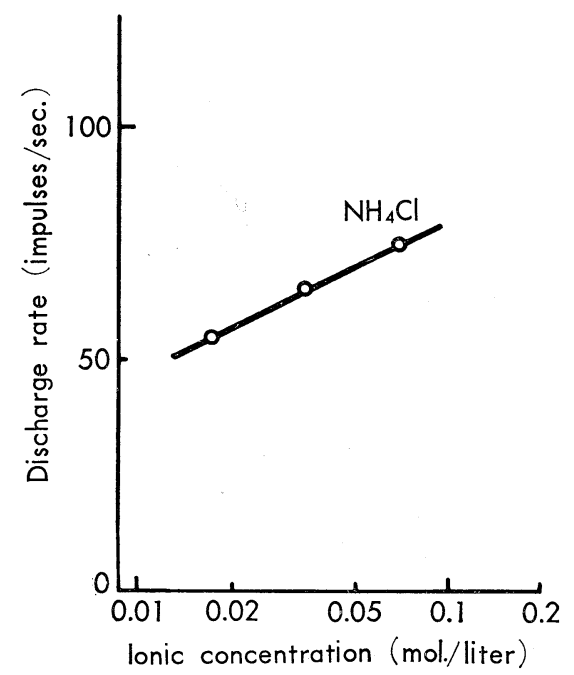

Fig. 8. Ammonium ion specific receptor. This fiber responded sensitively to $\mathrm{NH}_{4} \mathrm{Cl}$ solution, but was less sensitive to other cations. Material: The catfish (Ictalurus). $\mathrm{NaCl}, \mathrm{RbCl}$, TEA-Cl: No response.

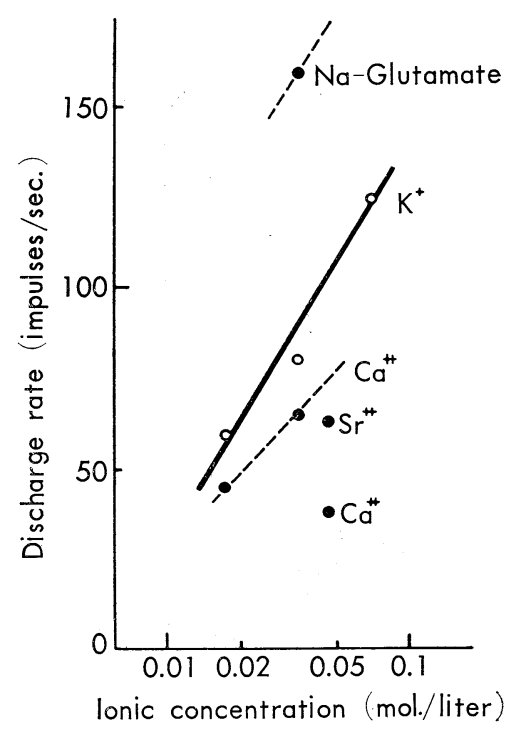

Fig. 9. Glutamate specific receptor. This fiber was highly sensitive to sodium glutamate of dilute concentration. Other salts, such as $\mathrm{KCl}, \mathrm{NaCl}, \mathrm{SrCl}_{2}$, $\mathrm{CaCl}_{2}$, were less effective than the sodium glutamate. Material: The catfish (Ictalurus).

Other fibers carried a response to a bitter substance such as quinine hydrochloride, but no response to other metallic ions (Fig. 11).

According to the experiments described above, it appears that most fishes, except the catfish, have receptors on the flank skin which send environmental information, such as the existence of monovalent cations, through the lateral-line nerve or the accessory lateral-line nerves. The catfish, on the other hand, has other receptors like taste buds, the terminal buds, comparable to those for gustatory sensation in higher animals, e.g., receptors for both monovalent and divalent cations together with those that are specifically sensitive to ammonium, glutamate or quinine (KuSANO, 1960). 


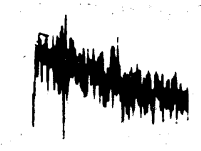

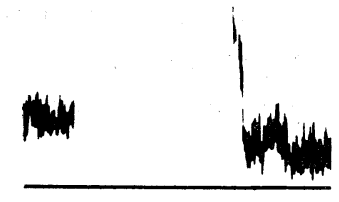

Na-glutamate $0.030 \mathrm{M}$

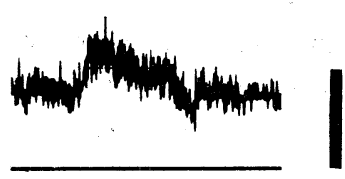

$50 \mathrm{impulses} / \mathrm{sec}$.

\section{$\mathrm{NaCl} \quad 0.069 \mathrm{M}$}

\section{$30 \mathrm{sec}$.}

Fig. 10. Response pattern of glutamate specific receptor.

Right: The response to $0.069 \mathrm{M}$ sodium chloride of the same receptor.

Left: The response to $0.03 \mathrm{M}$ sodium glutamate.

The concentration of $\mathrm{Na}^{+}$in the glutamate solution was less than half of that of the sodium chloride solution, but it produced a larger response.

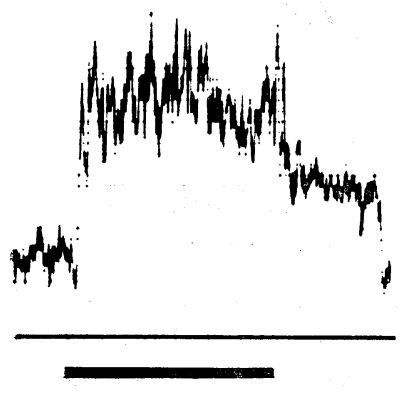

Quinine- $\mathrm{HCl}$

$1 / 200$

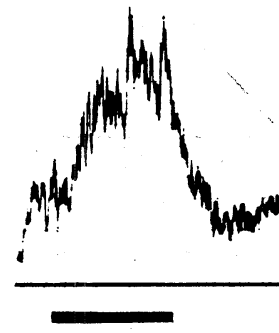

Quinine $-\mathrm{H}_{2} \mathrm{SO}_{4} \longrightarrow 30 \mathrm{sec}$.

$1 / 800$

Fig. 11. Response pattern of quinine sensitive fiber. Right: The response to $1 / 800 \mathrm{~g} / \mathrm{ml}$ quinine sulfate solution. Left: The response to $1 / 200 \mathrm{~g} / \mathrm{ml}$ quinine hydrochloride. The difference of the response magnitude may be caused by the difference of the bitterness of two chemicals and the solubility. Material: The catfish (Ictalurus).

\section{HISTOLOGY OF THE LATERAL-LINE ORGANS}

The structure of the receptors in the skin of fishes has been frequently studied and numerous reports were found in the older literature. HERrick (1903a, b) presented an extensive review and emphasized a distinction between function of the free neuromast and of the terminal bud as well as the different innervation 
of these two types of receptors. He reported that the neuromast was innervated by the lateral-line nerve, a branch of the vagus, while the terminal buds of the skin were innervated by the communis nerve, a branch of the facial. Recordings of electrical responses in the present report were mostly made from the lateral-line nerve, but some were also made from the dorsal or ventral branch of the accessory lateral-line nerve. The central branch of the accessory lateral-line nerve ran together with the lateral-line nerve, and separation of the fibers of the two nerves was impossible. The determination of the end organs involved therefore required some supplementary methods, i.e., light touch, rinsing with a salt solution, or stimulation with an electric current. Repeated experiments confirmed that the canal neuromasts did not respond to ionic solutions including monovalent cations. Therefore, if a receptor is innervated by a lateral-line nerve fiber that carries a response to a chemical solution, it may be considered a free neuromast or a pit organ.

In an extensive investigation of the anatomical patterns of the ramus lateralis accessorius, FreIHOFER (1963) concluded that this nerve innervated the terminal buds on the body surface, but pointed out that no modern neurophysiological methods had yet been applied. Therefore, the present report may be the first such investigation of this nerve in teleosts.

The lateral-line organs of the mullet are not inclosed in a canal as in other fish, but exist as separate free neuromasts in the groove of individual scales arranged in twelve or thirteen rows along the flank. Each scale of these rows that bears a neruromast, has a deep groove centrally along the body and at the base of the groove there is a small opening through which fibers from the lateral-line nerve pass to the neuromast located in the groove (Fig. 12). The body integument was studied in both the juvenile fish, $2-3 \mathrm{~cm}$ in length, and in the adult. The very young fish showed a number of small, free neuromasts with hairlike processes. These first appeared anteriorly along the body but at this stage neuromasts had not been sunken into scale grooves (IwAI, 1967). In the adult, the neuromast was large and had hairlike processes but no cupular material had been formed. Several free neuromasts existed at the level of the pectral fin or a little anteriorly. No other receptor organs were observed in histological sections or in total mounts of the flank integument. Experimental results obtained from electrophysiological studies showed that all responses to monovalent cations were almost similar, which were recorded from single fibers of the lateral-line nerve. Therefore, from both the histological and electrophysiological studies, we concluded that all responses carried by the lateral-line nerve in the mullet were from neuromasts and not from any terminal buds or taste buds on the body surface.

In contrast to the mullet, the situation in the catfish is quite different. The flank skin here has two kinds of pit organs, large and small, and also numerous terminal buds over virtually the entire body surface. The terminal buds are innervated by branches of rami from the ramus lateralis accessorius (VII) (HERRICK, 


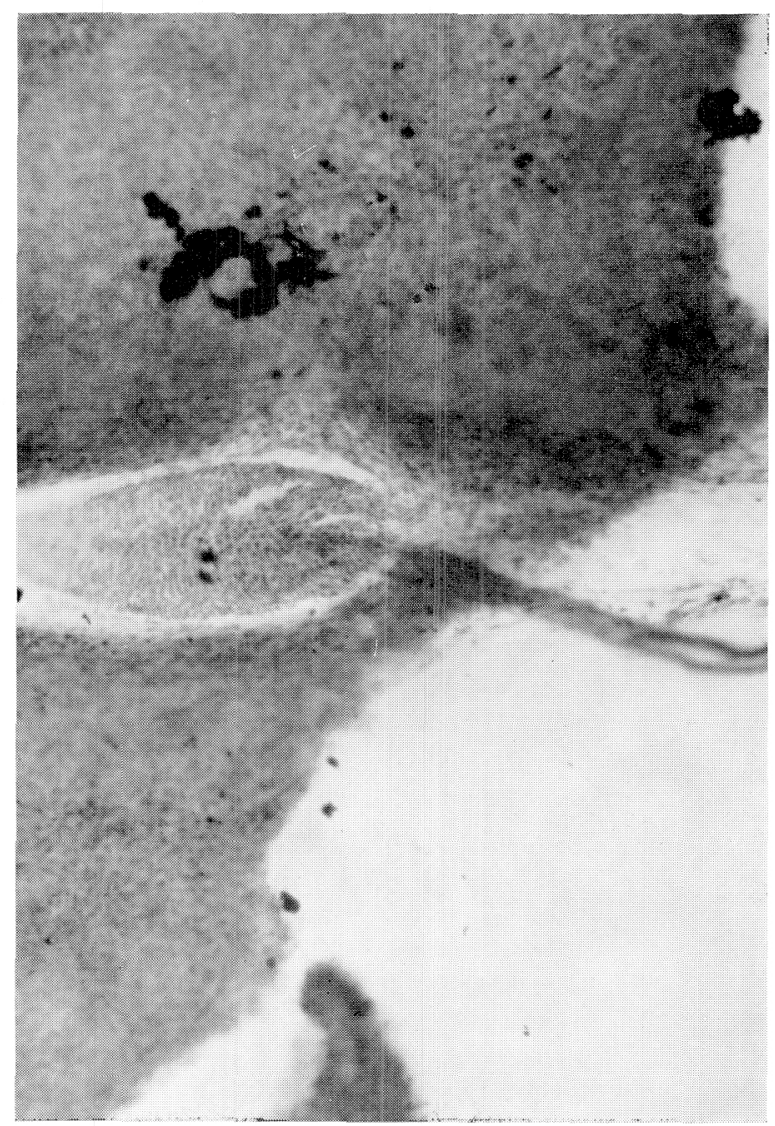

Fig. 12. Photograph from near the base of a removed mullet scale looking down on a neuromast $(220 \mu \times 80 \mu)$ located at the bottom of a groove. Sihler preparation.

1903a). The small pit organs were studied with an electron microscope and found to have microvilli but not cilia at the distal surfaces of the sensory cells (MULLinGER, 1964). Mullinger concluded that the small pit organ was an ampullary lateralline organ and might be an electroreceptor like that found in the weakly electric fishes (SzABO, 1965; WACHTEL and SzAmier, 1969). Later Dijkgraaf measured the threshold of this organ for electric current and found it responsive to less than $3 \mu \mathrm{V} / \mathrm{cm}$ of potential gradient (DIJKGRAAF, 1968). He described these organs as located on the ventral body area and innervated by the ventral branch of the ramus lateralis vagi $(\mathrm{X})$. Only the large pit organs were considered to be free neuromasts and mechanoreceptors innervated by the ramus lateralis vagi.

The small pit organ has a circular neuromast located at the basement level of the epidermis and is covered by mucus which fills the canal to the surface (Fig. 13). These receptors measure about $50 \mu \times 25 \mu$ with a canal $20 \mu$ in diameter and 


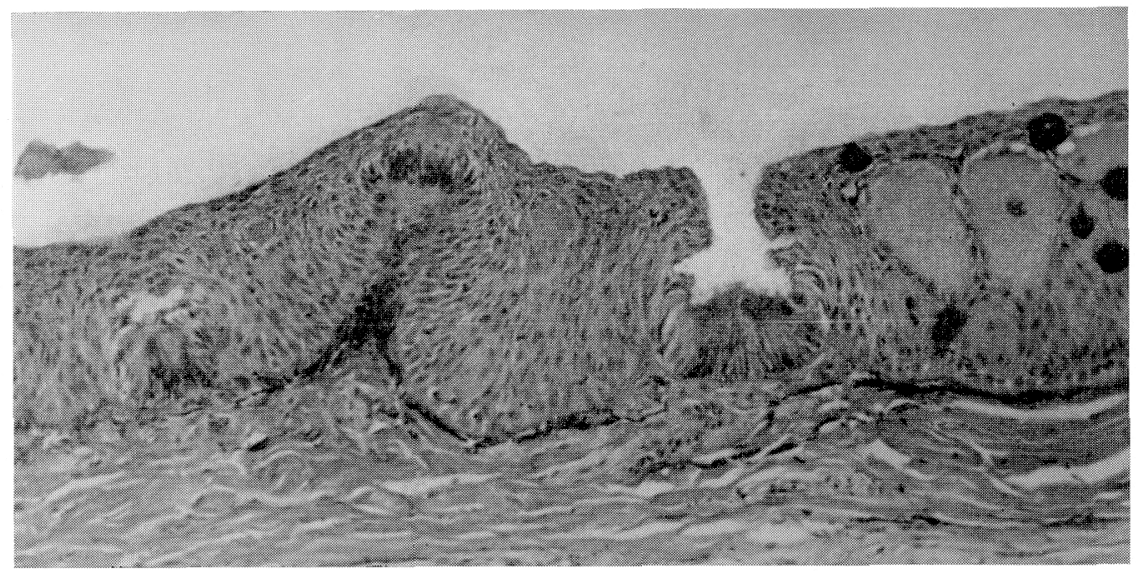

Fig. 13. Section of the flank skin of the catfish showing a terminal bud projecting slightly above the epithelial surface and a recessed small pit organ ( $50 \mu$ diameter) with a short canal opening to the surface. Photomicrograph: Mallory stained preparation. $10 \times$ obj., $10 \times$ oc.

$70 \mu$ in length. A few large pit organs were 4 to 5 times the small ones in size. The neuromasts, elliptical in shape, lay dorsally to and at right angles to the lateralline canal. These opened directly to the surface by a pore. No mucous covering was observed. Dijkgraaf's interpretation was based on Herrick's work (HerRICK, 1901) which considered the ramus lateralis vagi to innervate the lateral-line canal of the body and both the large and small pit organs. But the ramus lateralis did not take part in the innervation of the skin in general or the terminal buds. However, our results were obtained from fibers of the ramus lateralis vagi $(\mathrm{X})$ and ramus lateralis accessorius (VII) where most, though not all, origins of the nerve responses were determined by light touching or rinsing with salt solutions. These results might lead one to question Herrick's descriptions and conclusions.

HAMA and his associates (in preparation) have recently studied the similar pit organ of the conger eel and found the structure to be very like that of the canal neuromast of other fish.

In the carp, Cyprinus carpio, Herrick (1903a) found terminal buds over the entire body while IWAI (personal communication) reported terminal buds abundant in the head region but few terminal buds and many free neuromasts on the flank. Our electrophysiological investigations with fibers of the ramus lateralis vagi and the ramus lateralis accessorius demonstrated responses only to monovalent cations but not to other chemicals (Fig. 1). The response of the terminal bud on the flank might not have been observed in our investigation because of the limited number of the receptors. 


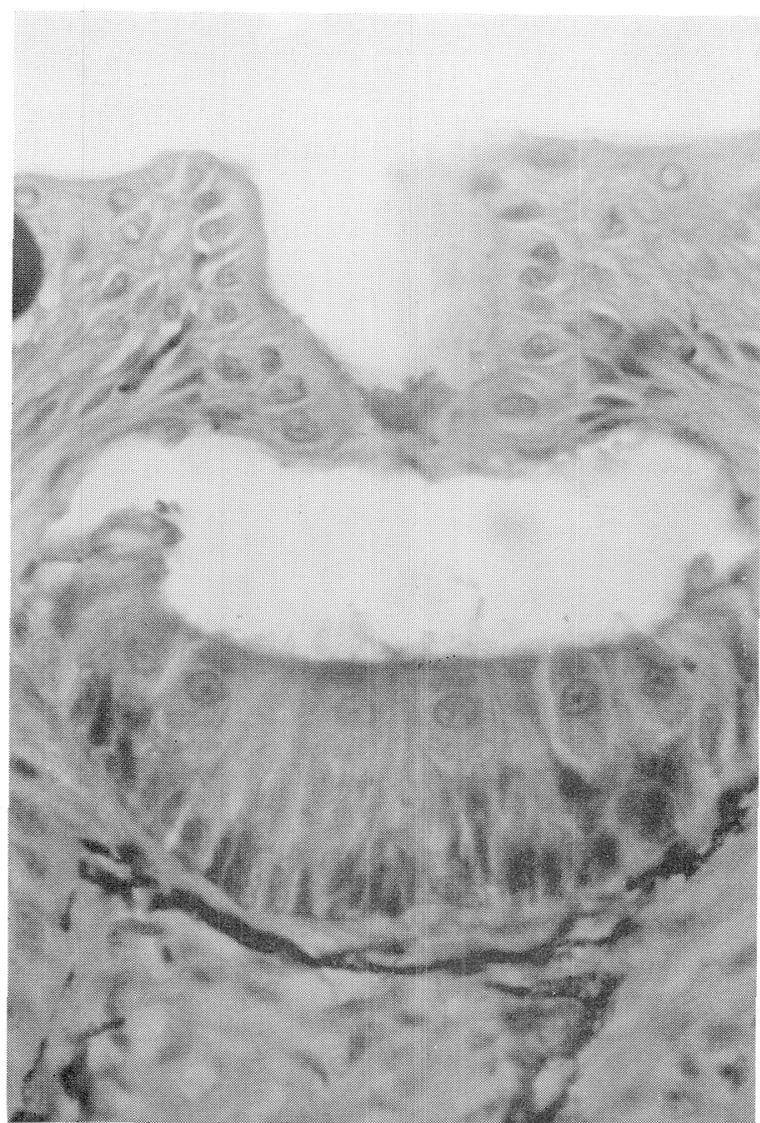

Fig. 14. Microphotograph of a small pit organ from the flank skin of the catfish showing the sensory and supporting cells and some mucus in the canal. $40 \times$ obj., $10 \times$ oc.

\section{DISCUSSION}

The monovalent cations were found to be remarkably effective as stimuli for the receptors innervated by nerve fibers of the ramus lateralis vagi $(X)$ and the ramus lateralis accessorius (VII) of the mullet and the carp, but not so for those of the catfish. The sensitivity of the receptor was also different between fresh water and marine fishes. The latter are in a medium containing an abundance of various salts; particularly abundant are the sodium ions, so that the receptor is not so sensitive to sodium as compared with other ions. This is shown in the case of the mullet and the shark (Katsuki and НаSнimoto, 1969; Kastuki et al., 1970). This may be due to adaptation of the cell membrane to the abundance of sodium ions. If so, the mullet that moves into fresh water from the sea should show a change in the salt sensitivity in response to the variation in the ionic environment: 
the present experiments with the mullet demonstrated a slow improvement of sensitivity of the end organ (receptor) to sodium ions until it almost reached the level of sensitivity to potassium. During this change a large amount of mucus was secreted and the body surface was covered with a thick coating of mucus which might function to protect the skin from sudden severe changes of the external environment until adjustment and recovery occurred as described in Fig. 5. Other internal systems, such as the osmoregulatory system might also be seriously affected. Further studies on this subject are in progress.

The situation in fresh water fish was quite different from that in marine fish since the contents of various salts in the environment were quite low, except in special accidental situations. Konishi and ZotTERMAN (1961), after working on the gustatory responses of the palatal organ in the carp, reported that 12 fibers showed a response to only $\mathrm{NaCl}$ solution in the 114 fibers studied, while responses to various salts and chemicals were recorded from other fibers. They did not study the nature of the fibers systematically, but it was quite clear that many fibers carried responses to various chemical solutions. The responses of the palatal organ contrasted with those of the lateral-line organs on the body surface which responded only to monovalent cations and not to other ions. Konishi and his associates (KoNISHI et al., 1966a, b; KoNISHI, 1967a; KoNISHI and HIDAKA, 1967b; KONISHI and HidAKA, 1969) also reported responses of the palatal organ to extremely dilute solutions of monovalent cations: the maximum responses were obtained from $\mathrm{Na}, \mathrm{K}, \mathrm{Li}$ and ammonium salts in $1 / 1024 \mathrm{M}-1 / 512 \mathrm{M}$ solutions. Increase in concentration decreased the responses. Salts with polyvalent cations and organic electrolytes did not elicit a response in this type of fibers at any concentrations, and a strong depression in the response was caused by the addition of divalent cations to the solution. The receptors responding specifically to dilute solutions of monovalent cations were distinguished from those responding well to the same cation in the greater concentration range. The magnitude of the resonse to the dilute solutions of salts depended on the valency of the anions; the larger was the valence, the greater the response to the same molar concentration of the salt solution was. The maximum responses were obtained from the following concentrations of various salt solutions: $1 / 4096 \mathrm{M}$ for $\mathrm{Na}_{4} \mathrm{Fe}(\mathrm{CN})_{6}$, $1 / 2048 \mathrm{M}$ for $\mathrm{Na}_{2} \mathrm{SO}_{4}$ and $1 / 1024 \mathrm{M}$ to $1 / 768 \mathrm{M}$ for $\mathrm{NaCl}$. These results suggest that the anionic effect should be considered (KonISHI, 1966b; KonISHI, 1967a). But these concentrations may be considered to have an identical cation concentration with $1 / 1024$ equivalent because each concentration is so incredibly dilute that the ionic dissociation may be almost complete. This may also suggest that the responses are caused by the cation in the applied solutions.

Onoda, one of our coworkers, observed a similar effect on the lateral-line organ of the carp of potassium in $1 / 1000 \mathrm{M}$ solution, a solution too dilute to evoke a salty taste in man. The fiber responsive to dilute potassium solution did not carry a response to more concentrated solutions, and this might indicate an ability of 
the fish for discrimination of a very small change in salt contents in the environment. The information sent along the fibers carrying responses of such chemical stimuli may be used in the animal for the selection of more suitable environmental conditions. In this sense the lateral-line organ may also act as a kind of primitive chemoreceptor. KUSANO (1960) found a similar gustatory fibers in the frog to those described above, but the threshold of these units for salts was much higher than those of the lateral-line receptors.

In contrast to the carp and mullet, the catfish has several chemical receptors. The terminal buds, which resemble the taste buds of the oral cavity, were abundantly found in histological sections in addition to large and small pit organs (HERRICK, 1901; Herrick, 1903a; Mullinger, 1964; Wachtel and Szamier, 1969). Responses to chemical stimulation of receptors innervated by lateral-line nerves were also found to be much more complicated than those of other fishes and may be due to the activity of the terminal buds. Terminal buds are distributed on the body of other fishes, but their number is not great when compared with that in the catfish.

The common eel, Anguilla japonica, is said to have a keen sense of smell. Some years ago KATSUKI et al. (1951) tried unsuccessfully to record responses to salt solutions transmitted along fibers of the lateral-line nerve in this fish. Recently similar experiments were repeated, but a few fibers of the accessory lateralline nerve, the end organs of which were found to be located on the fin, showed responses to chemical stimuli.

Such experimental results indicate that the number of chemical receptors on the flank varies among fishes and these differences may be correlated with the difference in the environment in which the fish lives, fresh, brackish, or salt water. The present study is not concerned with the receptors on the head. Although further studies are needed, the chemical sensation from the skin of fish is certainly related to the behavior of the fish in different environments, and this may be an important factor in fish ecology.

This study war supported by NSF grant GB-5768 and NIH grant NB 06890-02 to the Laboratory of Sensory Sciences, University of Hawaii. The authors wish to thank Dr. G. von Békésy for his encouragement and invaluable advice, the Oceanic Institute at Oahu, Hawaii, for supplying the fish, and Mr. K. Ogura for this technical assistance.

\section{REFERENCES}

BARDACH, J. E. (1967) The chemical senses and food intake in the lower vertebrates. In The Chemical Senses and Nutrition, ed. by Kare, M.R. and Maller, O. Johns Hopkins Press, pp. 19-43.

BARDACH, J. FuJITA, M. and Holl, A. (1967) Investigations of external chemoreceptors of fishes. In Olfaction and Teste, II, ed. by Hayashi, T. Oxford Pergamon Press, pp. 647-665.

BEIDLER, L. M. (1965) Comparison of gustatory receptors, olfactory receptors and free nerve 
endings. In Cold Spring Harbor Symposia on Quantitative Biology. Vol. XXX, pp. 191200.

DavenPort, H.A. (1964) In Histological and Histochemical Techniques, ed. by SAunders, W.B.

DijkgraAf, S. (1968) Electroreception in the catfish, Amiurus nebulosus. Experientia, 24: 187.

FLock, A. (1966) Ultrastructure and function in the lateral-line organs. In Lateral Line Detectors, ed. by CAHN, P. H. Indiana Univ. Press, pp. 163-197.

FreiHofer, W. C. (1963) Patterns of the ramus lateralis accessorius and their systematic significance in teleostean fishes. Stanford Ichthyol. Bull., 8 (2): 81-189.

FujIYA, M. and BARDACH, J. E. (1966) A comparison between the external taste sense of marine and fresh water fishes. Jap. Soc. Sci. Fisheries, 32 (1): 45-56.

Hama, K. (1965) Some observations on the fine structure of the lateral-line organ of the Japanese sea eel. J. Cell Biol., 24: 193-210.

HAMA, K. and YAMADA, K. Personal communication.

HASLER, A. D. (1957) Olfactory and gustatory senses of fishes. In The Physiology of Fishes, ed. by Brown, M. E. Vol. II, Acad. Press, N.Y., pp. 187-209.

Herrick, C. J. (1901) The cranial nerves and cutaneous sense organs of the North American Siluroid fishes. J. Comp. Neurol., 11: 177-249.

Herrick, C. J. (1903a) The organ and sense of taste in fishes. U.S. Fish Comm., 22: 237-271.

Herrick, C. J. (1903b) On the morphological and physiological classification of the cutaneous sense organs of fishes. Amer. Naturalist, 37: 313.

IWAI, T. Personal communication.

IWAI, T. (1967) Structure and development of lateral line cupulae in teleost larvae. In Lateral Line Detectors, ed. by CAHN, P. H. Indiana Univ. Press, pp. 27-44.

Katsuki, Y., Yoshino, S. and Chen, J. (1951) Action current of the single lateral-line nerve fiber of fish. II. Jap. J. Physiol., 1: 179-194.

Katsuki, Y., Yanagisawa, K., Tester, A. L. and Kendall, J. I. (1969) Shark pit organ: responses to chemicals. Science, 163: 405-407.

Katsuki, T. and Hashimoto, T. (1969) Chemoreception in the lateral-line system of the bony fish. Proc. Jap. Acad., 45: 209-214.

Katsuki, Y., Hashimoto, T. and Yanagisawa, K. (1970) The lateral-line organ of shark as a chemoreceptor. Advan. in Biophys., 1: 1-51.

Konishi, J. and Zotterman, Y. (1961) Taste functions in the carp. Acta Physiol. Scand., 52: 150-161.

Konishi, J. and Zotterman, Y. (1963) Taste functions in fish. In Olfaction and Taste, ed. by ZotTerman, Y. Oxford Pergamon Press, pp. 215-233.

Konishi, J., UchidA, M. and Mori, Y. (1966a) Gustatory fibers in the sea catfish. Jap. J. Physiol., 16: 194-204.

Konishi, J. (1966b) Fresh water fish chemoreceptors responsive to dilute solutions of electrolytes. J. Gen. Physiol., 49: 1241-1264.

Konishi, J. (1967a) Studies on the stimulation of chemoreceptors of fresh water fish by dilute solutions of electrolytes. In Olfaction and Taste, II, ed. by HAYASHI, T. Oxford Pergamon Press, pp. 667-692.

Konishi, J. and HidaKA, I. (1967b) Stimulation of the chemoreceptors of the sea catfish by dilute electrolyte solutions. Jap. J. Physiol., 17: 726-745.

Konishi, J. and HidakA, I. (1969) On the stimulation of fish chemoreceptors by dilute solutions of polyelectrolytes. Jap. J. Physiol., 19: 315-326.

KusANO, K. (1960) Analysis of the single unit activity of gustatory receptors in the frog tongue. Jap. J. Physiol., 10: 620-633.

Mullinger, A. M. (1964) The fine structure of ampullary electric receptors in Amiurus. 
Proc. Roy. Soc., 160: 345-357.

ONODA, N. In preparation.

SzABo, T. (1965) Sense organs of the lateral-line system in some electric fish of the Gymnotidae, Mormyridae and Gymnarchidae. J. Morph., 117: 229-250.

TAtedA, H. (1964) Taste response of the isolated barbel of the catfish. Comp. Biochem. Physiol., 11: $367-378$.

Teichman, H. (1962) Die Chemorezeption der Fische. Ergeb. Biol., 25: 177-205.

TesTer, A. L. and Kendall, J. I. (1967) Innervation of free and canal neuromasts in the sharks Carcharhinus menisorrah \& Sphyrna lewini. In Lateral Line Detectors, ed. by CAHN, P. H. Indiana Univ. Press, pp. 53-72.

UgA, S. and Hama, K. (1967) Electron microscopic studies on the synaptic region of the taste organ of carps \& frogs. J. Elect. Micr., 16: 269-275.

WaChTEL, A. W. and Szamier, R. B. (1969) Special cutaneous receptor organs of fish. $J$. Morph., 128: 291-308.

Whitear, M. (1952) The innervation of the skin of teleost fishes. Quart J. Microsc. Sci., 93: 289-305. 